\title{
PHYSA CUBENSIS PFEIFFER, 1839 (PULMONATA: PHYSIDAE)
}

\author{
W. LOBATO PARAENSE
}

Instituto Oswaldo Cruz, Departamento de Malacologia, Caixa Postal 926, 20001, Rio de Janeiro, RJ, Brasil

A description of Physa cubensis Pfeiffer, 1839, based on 15 specimens collected in Havana, Cuba, is presented.

The shell, measuring $9.0 \times 4.8 \mathrm{~mm}$ to $12.3 \times 6.4 \mathrm{~mm}$, is ovate-oblong, thin, diaphanous, horncolored, shining. Spire elevated, broadly conical; protoconch distinct, roundish, reddish-brown. About five moderately shouldered, roundly convex whorls, penultimate whorl expanded; spiral striation subobsolete; growth lines faint on the intermediate whorls, clearly visible on the body whorl, crowded here and there. Suture well impressed. Aperture elongated, $2.05-2.67$ /mean 2.27) times as long as the remaining length of the shell, narrow obovate-lunate; upper half acuteangled, lower half oval, narrowly rounded at the base; outer lip sharp, inner lip completely closing the umbilical region; a thick callus on the parietal wall; columellar plait well marked. Ratios: shell width/shell length $=0.52-0.61$ (mean 0.55); spire length $/$ shell length $=0.27-0.33($ mean 0.31$)$; aperture length $/$ shell length $=0.67-0.73$ (mean 0.69).

Oral lappets laterally mucronate; foot spatulate with acuminate tail. Mantle reflection with 6.8 short triangular dentations in the right lobe (columellar side) and $4-6$ in the left lobe (near the pneumostome).

Renal tube tightly folded into a zigzag course.

Ovotestis, ovispermiduct, seminal vesicle, oviduct, nidamental gland, uterus and vagina as in Physa marmorata (see Paraense, 1986, Mem. Inst. Oswaldo Cruz, 81: 459-469). Spermathecal body egg-shaped or pear-shaped; spermathecal duct uniformly narrow with expanded base, a little longer than the body.

Spermiduct, prostate and vas deferens as in $\mathrm{P}$. marmorata (Paraense, loc. cit.). Penis wide proximally, narrowing gradually apicad; penial canal with subterminal outlet. Penial sheath following the width of the penis and ending up by a bulbous expansion somewhat narrower than the proximal portion. Penial sheath/prepuce ratio $=1.25-1.83$ (mean 1.49). Prepuce much wider than the bulb of the penial sheath, moderately shouldered owing to the intromission of the bulb, and with a large gland in one side of its proximal half occupying about a third of its length. Extrinsic muscles of the penial complex as in $\mathrm{P}$. marmorata.

Jaw a simple obtusely V-shaped plate. Radula to be described separately.

Kcy words: Mollusca - Physidac - Physa cubensis - Taxonomy

According to Aguayo (1938), rnysa cubensis is "the commonest fluvial mollusc in Cuba, being found in practically all flowing and stagnant waters in the Island". It has been recorded from several islands of the West Indies, and from southern Florida and eastern South America down to southern Brazil. Its original description reads as follows (Pfeiffer, 1839: 354, not figured):

45. Physa cubensis Pfr. - Testa sinistrorsa ovali, solidula fusco-cornea; anfract. 5 striatis, interdum subvaricosis, ultimo inflato; columelia callosa, torta; apertura ovatooblonga. Long. 6, diam. 33 ,'”. - Sehr ähnlich unsrer europäischen Ph. acu ta Dr.

Received A pril 24, 1986.

Accepted May 20, 1986.
In this paper a description of $P$. cubensis is presented, based on 15 specimens collected by myself, together with my friend, the Cuban malacologist Miguel Jaume, on December 4, 1956, from a pond in the Country Club of Havana, district of Marianao, where they occurred in syntopy with the planorbid Biomphalaria havanensis.

Each specimen was killed by gradual immersion in water heated to $700 \mathrm{C}$, with the aperture upward, so carefully as to minimize its retracting back to the shell. Af ter $20 \mathrm{sec}$ the snail was completely plunged for 20 additional sec and then transferred to water at room temperature. The animal (under water) was drawn from the shell with a forceps and fixed in Railliet-Henry's fluid (distilled water $930 \mathrm{ml}$, sodium chloride $6 \mathrm{~g}$, formalin $50 \mathrm{ml}$, glacial acetic acid $20 \mathrm{ml}$ ). One specimen was embedded in paraffin, sectioned serially and stained with hematoxylin-eosin for microanatomical observation. 


\section{DESCRIPTION}

The shell size in the studied sample ranges from $9.0 \times 4.8 \mathrm{~mm}$ to $12.3 \times 6.4 \mathrm{~mm}$, the largest one being shown in Fig. 1. The shell is ovate-oblong, thin, horn-colored, with about five moderately shouldered, roundly convex whorls, penultimate whorl expanded; spire elevated, broadly conical; sutures well impressed. The shell is encrusted to a variable extent with a black coat which grows thinner from the apex to the aperture and shows a positive Prussian blue reaction indicating that it results from adsorption by the shell surface of ferric oxide present in lateritic soils. If the crust is soaked in Dakin's solution and then removed with a camel's-hair brush, the shell will show a shining surface and a diaphanous wall with faint growth lines on the intermediate whorls which become clearly visible on the body whorl and may be crowded here and there; spiral striation subobsolete; protoconch distinct, roundish, reddishbrown; growth lines risen and packed together along the lower margin of the suture, giving the sutural belt a shirred appearance; subsutural line reddish-brown, yellowish or white.

The aperture is elongated, 2.05 to 2.67 times (mean 2.27) as long as the remaining length of the shell, narrow obovate-lunate; upper half acute-angled, lower half oval, narrowly rounded at the base; ou ter lip sharp, inner lip completely closing the umbilical region; a thick callus on the parietal wall; columellar plait well marked.

Ratios between shell measures: shell width/ shell length $=0.52$ to 0.61 (mean 0.55 ); spire lenght/shell length $=0.27$ to 0.33 (mean 0.31 ); aperture length $/$ shell length $=0.67$ to 0.73 (mean 0.69).

Since in the following anatomical description comparison is made with Physa marmorata, the reader is referred to my previous paper on that species (Paraense, 1986).

Some characters of the exposed soft parts, such as the shape of the oral lappets and foot, more properly observed in live animals, could not be fully appreciated, seeing that only preserved specimens were examined. Anyway, it seems that they do not differ significantly from those of $P$. marmorata. The pigmentation of the cephalopodal mass is much lighter than in $P$. marmorata, there having no concentration of melanin in the foot tail. The pigment pattern on the roof of the pulmonary cavity is much the same as in $P$. marmorata, but in every specimen the area over the attachment of the physid muscle is unpigmented (Fig. 2).

The degree to which the mantle extension is reflected over the shell cannot be ascertained. It is furnished with short projections (Fig. 3) which seem to be more acute and less interspaced than the dentations present in $P$. marmorata (an accurate comparison would require well relaxed specimens of $P$. cubensis). The dentations vary in number from 3 to 5 in the left lobe (near the pneumostome) and from 6 to 8 in the right lobe (on the columellar side).

\section{The renal tube is similar to that of $P$. mar- morata.}

The genital system is shown in Fig. 4. The hermaphroditic and female ducts show the same characteristics as in $P$. marmorata, except for the spermatheca, which has an egg-shaped or pear-shaped body and a narrow duct a little longer than the body.

The prostate looks like that of $P$. marmora$t a$, showing about 20 diverticula. With the exception of the penial complex, no differences were found in the other sections of the male system.

The penis, free within the penial sheath, is about as long as the membranous portion of the latter. It is proximally swollen, decreasing gradually in width toward its free end; it has an axial canal with a subterminal outlet (Fig. 5). The penial sheath is much wider proximally than in $P$. marmorata, narrowing very gradually to about $1 / 3 \cdot 1 / 4$ of its proximal wid th, and ending as a bulbous expansion somewhat narrower than the proximal end (in $P$. marmorata the bulb is much wider than the proximal end). As in P. marmorata, the tip of the bulb is inserted into and cohered with the caudal end of the prepuce. Histologically the penial sheath shows the same structure as described for $P$. marmorata. Its inserted end apart, it is about $1.49(1.25$ to 1.83$)$ times as long as the prepuce. The prepuce, much wider than the bulb of the penial sheath, has a moderately shouldered caudal end as a result of the intromission of the bulb of the penial sheath. As in P. marmorata, there are two pilasters in the preputial wall. A large gland in one side of the proximal half of the prepuce occupies an ovoid area about one third of the length of that organ.

The extrinsic muscles of the penial complex (retractor and protractors) show the same disposition as in $P$. marmorata.

Egg capsules and eggs were not observed.

The jaw is a single obtusely V-shaped plate, similar to that of $P$. marmorata. The radula will be studied separately. 

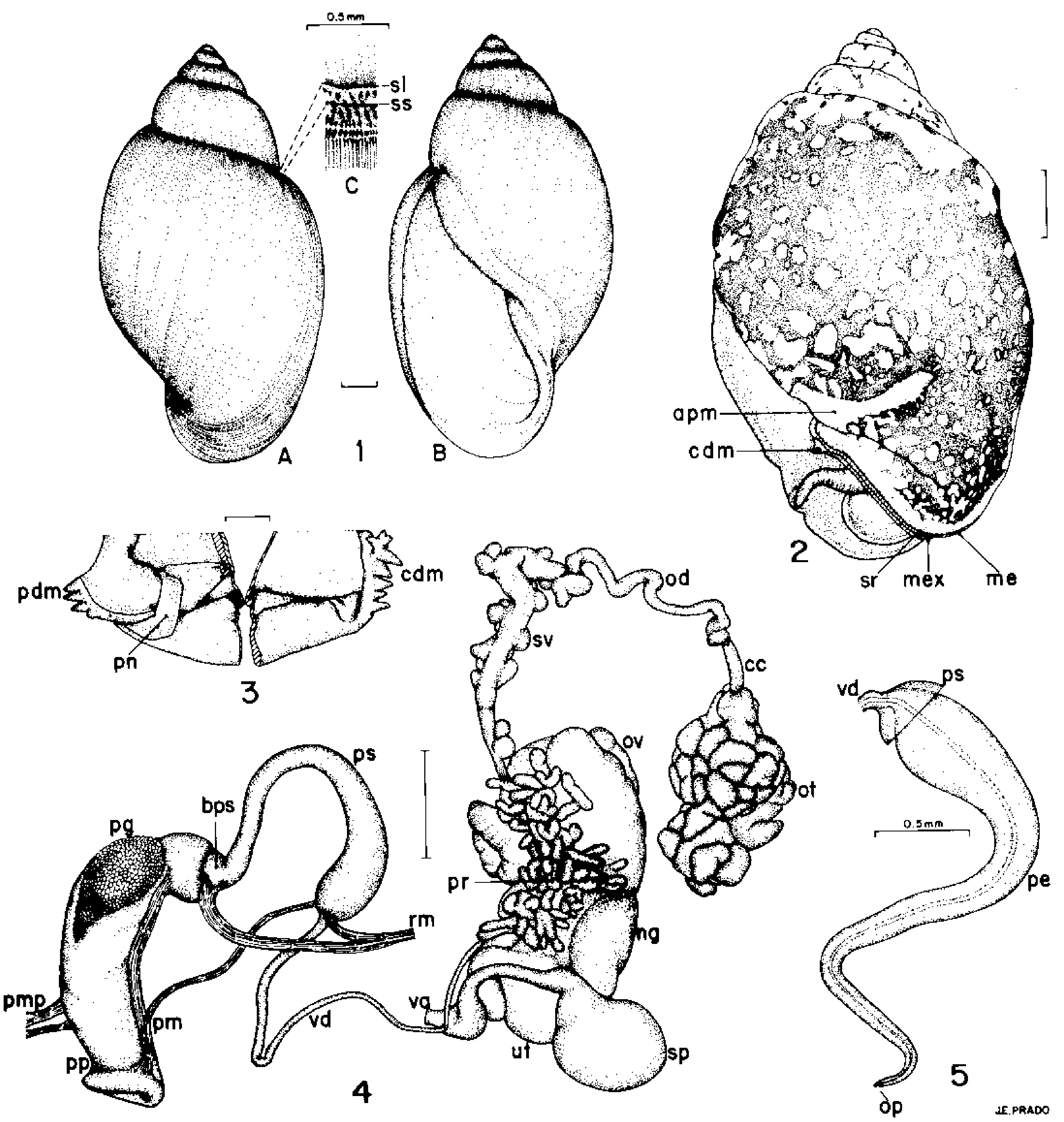

Physa cubensis - Fig. 1: shell of specimen from Havana, Cuba $(\mathrm{A}=$ dorsal view, $\mathrm{B}=$ ventral view, $\mathrm{C}=$ suture area enlarged). Fig. 2: outer surface of mantle. Fig. 3 : inner surface of mantle margin showing left and right lobes of mantle refiection. Fig. $4:$ genital system. Fig. $5:$ penis. - apm $=$ area of insertion of physid muscle, bps $=$ bulb of penial sheath, $c c=$ collecting canal of ovotestis, $\mathrm{cdm}=$ columellar dentation of mantle, me $=$ mantle edge, mex $=$ mantle extension, $\mathrm{ng}=$ nidamental gland, $\mathrm{od}=$ ovispermiduct, op $=$ outlet of penial canal, ot $=$ ovotestis, ov = oviduct, $\mathrm{pdm}=$ parietal dentation of mantle, $\mathrm{pe}=$ penis, $\mathrm{pg}=$ preputial gland, $\mathrm{pm}=$ protractor muscle of penial complex, pmp $=$ protractor muscle of prepuce, $\mathrm{pn}=$ pncumostome, $\mathrm{pp}=$ prepuce, $\mathrm{pr}=$ prostate, $\mathrm{ps}=$ penial sheath, $\mathrm{rm}=$ retractor muscle of penial complex, $\mathrm{sl}=$ suture line, $\mathrm{sp}=$ spermatheca, $\mathrm{sr}=$ supramarginal ridge, $\mathrm{ss}=$ subsutural line, $\mathrm{sv}=$ seminal vesicle, $u t=$ uterus, $\mathrm{va}=$ vagina, $\mathrm{vd}=$ vas deferens. - Bar (unless otherwise stated) $=1 \mathrm{~mm}$. 

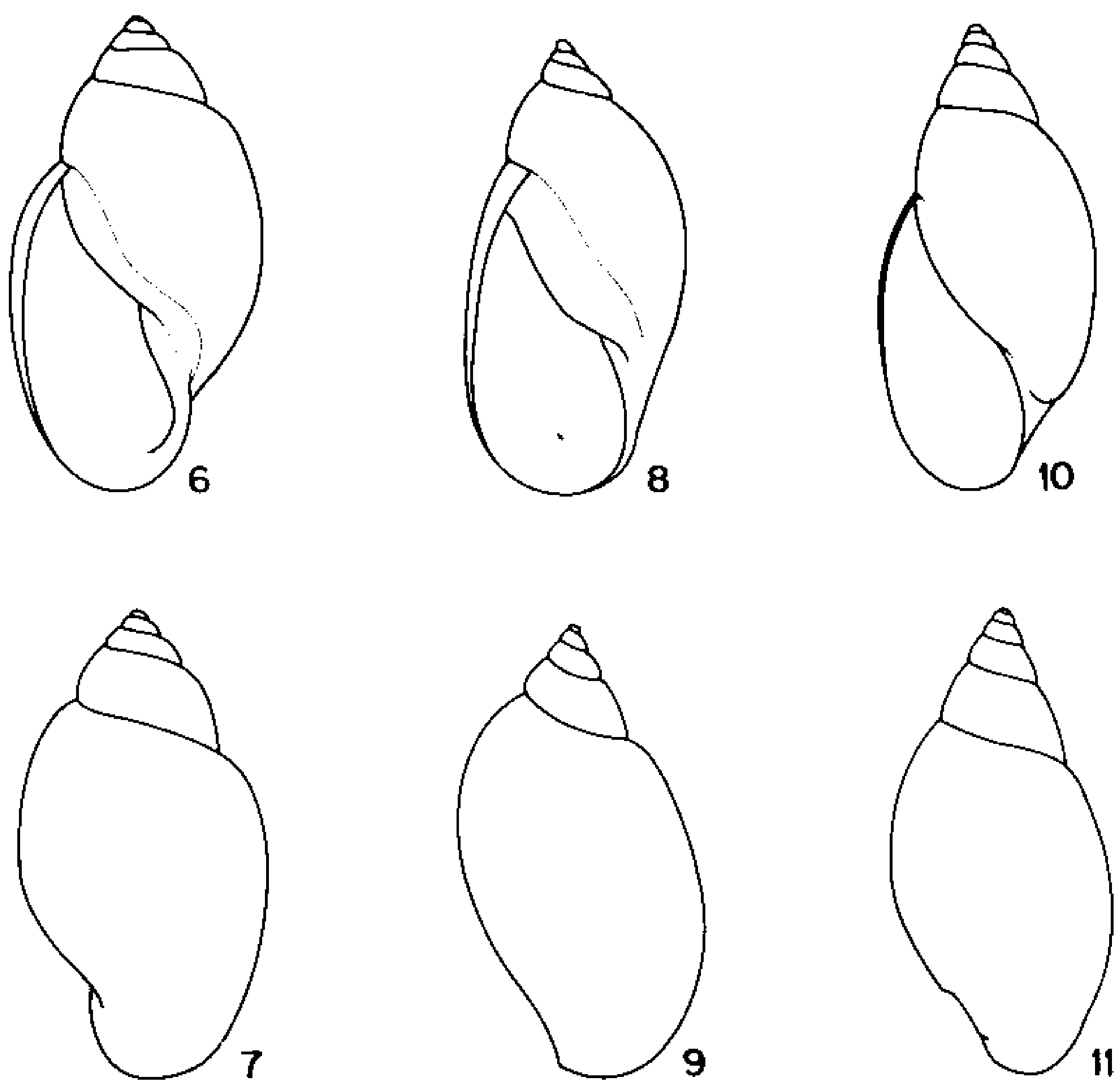

Figs. 6, 7: shell of Physa cubensis. Figs. 8, 9: shell of Physa sowerbyana, from Orbigny's (1841) Plate 12, Figs. 11, 12 (enlarged). Figs. 10, 11: shell of Physa marmorata, from Paraense (1986).

\section{REMARKS}

A comparison between $P$. cubensis and $P$. marmorata shows the following significant differences:

$\begin{array}{lll} & \text { P.cubensis } & \text { P. marmorata } \\ \text { Whorls } & \begin{array}{l}\text { Roundly convex, } \\ \text { moderately shouldered }\end{array} & \begin{array}{l}\text { Flatiy convex } \\ \text { not shouldered }\end{array} \\ \text { Spire } & \text { Lower, wider } & \text { Higher, narrower } \\ \text { Suture } & \text { Well impressed } & \text { Shallow } \\ \text { Columellar plait } & \text { Well marked } & \text { Low } \\ \text { Shell width/shell length } & \text { Mean } 0.55 & \text { Mean } 0.47 \\ \text { Spire length/shell length } & \text { Mean } 0.31 & \text { Mean } 0.39 \\ \text { Aperture lenght/shell length } & \text { Mean } 0.69 & \text { Mean } 0.62 \\ \text { Penial canal } & \text { Subterminal outlet } & \text { Lateral outlet } \\ \text { Bulb of penial sheath } & \text { Somewhat narower than } & \text { Much wider than proximai } \\ & \text { proximal end of sheath } & \text { end of sheath } \\ \text { Preputial gland } & \text { Present } & \text { Absent } \\ \text { Penial sheath/prepuce } & \text { Mean } 1.49 & \text { Mean } 2.08\end{array}$


Although no general inference may be expected from the observation of only two species, a comparison between them shows that they are ascribable to separate genera.

$P$. marmorata has been placed under Aplexa Fleming and Stenophysa Martens. The type species of Aplexa, Physa hypnorum (L.), has a smooth mantle edge (without digitations or dentations) and, as shown by Slugocka (1913), its penial canal has a terminal outlet. These two features exclude $P$. marmorata from Aplexa.

So far Stenophysa has not been defined on sound anatomical grounds. Physa sowerbyana Orbigny, its type species, is a new replacement name for Physa rivalis (Sowerby); the latter, which had been adopted by Orbigny (1835, 1837 , not figured) for the species he collected in Argentina, Uruguay, Brazil, Peru and Chile, was replaced after him having realized that (translated) "it had been given to Physa fontinalis Draparnaud (Bulla fontinalis L.) by Dilwin" (Orbigny, 1841:191). Physa sowerbyana, therefore, brings back all the confusion that involves $P$. rivalis (see, for instance, Clench, 1930, and Parodiz, 1956).

According to Orbigny (1841:191), P. sowerbyana is common in Martinique and Cuba, reaching a greater size in the latter. Aguayo (1938: 264), with the authority of a resident malacologist, stated that only two species ( $P$. cubensis and $P$. bermudezi) did occur in Cuba, considering the finding of $P$. sowerbyana in the island doubtful. If the shell of $P$. sowerbyana depicted in Orbigny's Plate 12, Figs. $11,12(1841)$ is confronted with those of $P$. marmorata and P. cubensis, as in Figs. 6 to 11 of the present paper, it will show a greater degree of similarity with the latter. This fact, added to Aguayo's (1938:268-269) comment that the occurrence of $P$. sowerbyana in Cuba had been indicated by only two authors (Orbigny and Gibbons), points to the possibility of $P$. sowerbyana being a synonym of $P$. cubensis. ${ }^{*}$

$P$. cubensis has been placed in the genus Physella Haldeman, whose type species (Physa globosa Haldeman) has not yet been adequately investigated anatomically.

The above reasons justify the present difficulty in solving the generic problem

There is a good deal of agreement between the tax onomic characters of $P$. cubensis mentioned in common in the above description (HA, for Havana) and in Te's (1978) study of Phy-

* Added in proof. - I regret having overlooked a record by J. T. Milcra \& M. L. Jaume (1981, Miscelanea Zoologica, 12: 1-2) of Aplexa (Stenophysa) marmorata (as a senior synonym of Physa sowerbyana) from a small pond at Vento, Havana city, in 1978. sidae (FL, for Florida): shell as a whole, shell spire and aperture, shape of penial complex, shell width/shell length $(\mathrm{HA}=0.52-0.61$, mean $0.55 ; \mathrm{FL}=0.55$ ), spire length/shell length $(\mathrm{HA}=0.27-0.33$, mean $0.31 ; \mathrm{FL}=0.34)$, penial sheath/prepuce $(\mathrm{HA}=1.25-1.83$, mean $1.49 ; \mathrm{FL}=$ ca. 1.50 ).

\section{RESUMO}

É apresentada uma descrição da espécie Physa cubensis Pfeiffer, 1839, baseada em material coletado em Havana, Cuba. Foram examinados 15 exemplares medindo de $9.0 \times 4.8 \mathrm{~mm}$ a $12.3 \times 6.4 \mathrm{~mm}$, com os séguintes caracteres:

Concha oval-oblonga, delgada, diáfana, de coloração córnea, superfície lustrosa. Espira elevada, largamente cônica; protoconcha distinta, arredondada, parda-avermelhada. Cerca de cinco giros com ombro moderadamente saliente, convexos-arredondados, o penúltimo expandido; linhas espirais pouco perceptiveis; linhas de crescimento delgadas nos giros intermediários, mais nítidas no giro corporal, aglomeradas em algumas áreas. Sutura bem impressa. Abertura alongada, 2.05 a 2.67 vezes (média 2.27) mais longa que o resto do comprimento da concha, em crescente oboval; metade superior acutangular, metade inferior oval, estreitamente arredondada na base; lábio externo cortante, lábio interno fechando completamente a região umbilical; calo espesso na superfície parietal; dobra columelar saliente. Razóes: largura da concha/comprimento da concha $=0.52$ - 0.61 (média 0.55); comprimento da espira/ comprimento da concha $=0.27 \cdot 0.33$ (média 0.31 ); comprimento da abertura/comprimento da concha $=0.67-0.73$ (média 0.69)

Mufla mucronada lateralmente. Pé espatulado com cauda acuminada. Reflexão do manto com 6 - 8 denteações triangulares curtas no lobo direito (lado columelar) e 4 - 6 no lobo esquerdo (perto do pneumóstomo).

Tubo renal descrevendo curvas muito unidas, em ziguezague.

Ovoteste, ovispermiduto, vesícula seminal, oviduto, glândula nidamental, útero e vagina como em Physa marmorata (ver Paraense, 1986, Mem. Inst. Oswaldo Cruz, 81:459-469). Corpo da espermateca ovóide ou piriforme, canal uniformemente estreito, dilatado na base e pouco mais longo que o corpo.

Espermiduto, próstata e canal deferente como em $P$. marmorata (Paraense, loc. cit.). Pênis grosso na parte proximal, diminuindo gradualmente de diâmetro para a extremidade livre, percorrido por um canal axial com abertura subterminal. Bainha do pênis acompanhando a largura do pênis $e$ terminando por uma expansão bulbóide glandular um pouco mais estreita que a parte proximal. Razão en- 
tre comprimentos da bainha do pênis e do prepúcio $=1.25-1.83$ (média 1.49). Prepúcio muito mais largo que o bulbo da bainha do pênis, com ombro pouco saliente resultante da intromissão do bulbo, e com volumosa glândula em um lado da metade proximal da parede do prepúcio, ocupando cerca de um terço do comprimento deste órgão. Músculos extrínsecos do complexo peniano como em $P$. marmorata.

Mandíbula formada por uma placa simples em V obtuso. Rádula a ser descrita em outro trabalho.

Palavras-chave: Mollusca - Physidae - Physa cubensis - taxionomia.

\section{REFERENCES}

AGUAYO, C. G., 1938. Los moluscos fluviatiles cubanos. Mem. Soc. Cubana Hist. Nat., 12 (4): 253276.

CLENCH, W. J., 1930. Notes on Physidae with de- scriptions of new species. Occ. Pap. Boston Soc. Not. Hist., 5: 301-315.

ORBIGNY, A., 1835. Synopsis terrestrium et fluviatilium molluscorum, in suo per American Meridionalem itinere collectorum. Mag. Zool., 5, Cl. 5 $(61-62): 1-44$

ORBIGNY, A., 1837. Voyage dans l'Amérique méridionale. Mollusques, 5 (3). P. Bertrand, Paris.

ORBIGNY, A., 1841. Mollusques, 1. In RAMON DE LA SAGRA: Histoire physique, politique et naturelle de l'ille de Cuba. A. Bertrand, Paris.

PARAENSE, W. L., 1986. Physa marmorata Guilding, 1828 (Pulmonata: Physidae). Mem. Inst. Oswaldo Cruz, 81 (4): 459-469.

PARODIZ, J. J., 1956. Notas sobre Physa. Neotropica, $2(7): 19-21$.

PFEIFFER, L., 1839. Bericht über die Ergebnisse mejner Reise nach Cuba im Winter 1838-1839. Arch. Naturgesch., 5 (1): 346-358.

SLUGOCKA, M., 1913. Recherches sur l'appareil génital des Gastćropodes puimonés du genre Physa. Rev. Suisse Zool., 21 (3): 75-109.

TE, G. A., 1978. A systematic study of the family Physidae (Basommatophora: Pulmonata). Ph. D. Thesis. Univ. Michigan, xii +324 p. Univ. Microfilms International. Ann Arbor, Mich. 